University of Nebraska - Lincoln

DigitalCommons@University of Nebraska - Lincoln

Nebraska Cooperative Fish \& Wildlife Research Nebraska Cooperative Fish \& Wildlife Research Unit -- Staff Publications

$1-2012$

\title{
Land Use, Landscapes, and Biological Invasions
}

\author{
Karie L. Decker \\ USGS Nebraska Cooperative Fish and Wildlife Research Unit, kdecker4@unl.edu \\ Craig R. Allen \\ USGS Nebraska Cooperative Fish and Wildlife Research Unit, University of Nebraska, callen3@unl.edu \\ Leonardo Acosta \\ University of Nebraska-Lincoln \\ Michelle L. Hellman \\ University of Nebraska-Lincoln \\ Christopher F. Jorgensen \\ University of Nebraska-Lincoln \\ See next page for additional authors
}

Follow this and additional works at: https://digitalcommons.unl.edu/ncfwrustaff

Part of the Other Environmental Sciences Commons

Decker, Karie L.; Allen, Craig R.; Acosta, Leonardo; Hellman, Michelle L.; Jorgensen, Christopher F.; Stutzman, Ryan J.; Unstad, Kody M.; Williams, Amy; and Yans, Matthew, "Land Use, Landscapes, and Biological Invasions" (2012). Nebraska Cooperative Fish \& Wildlife Research Unit -- Staff Publications. 99. https://digitalcommons.unl.edu/ncfwrustaff/99

This Article is brought to you for free and open access by the Nebraska Cooperative Fish \& Wildlife Research Unit at DigitalCommons@University of Nebraska - Lincoln. It has been accepted for inclusion in Nebraska Cooperative Fish \& Wildlife Research Unit -- Staff Publications by an authorized administrator of DigitalCommons@University of Nebraska - Lincoln. 


\section{Authors}

Karie L. Decker, Craig R. Allen, Leonardo Acosta, Michelle L. Hellman, Christopher F. Jorgensen, Ryan J. Stutzman, Kody M. Unstad, Amy Williams, and Matthew Yans 


\title{
Land Use, Landscapes, and Biological Invasions
}

Karie L. Decker, Craig R. Allen, Leonardo Acosta, Michelle L. Hellman, Christopher F. Jorgensen, Ryan J. Stutzman, Kody M. Unstad, Amy Williams, and Matthew Yans*

\begin{abstract}
The negative effect of invasive species on native species, communities, and ecosystems is widely recognized, and the economic effects in the United States are estimated to be billions of dollars annually. Studies often examine traits of nonnative species or examine what makes a particular habitat invasible. To better understand the factors governing invasions, we used the flora of Nebraska to characterize and compare native and nonnative plant occurrences throughout the state. In addition, we assessed four critical landscape predictors of nonnative plant richness: human population size and three land cover attributes that included percentage of grassland, percentage of agriculture, and percentage of public lands. Results indicated that individual plant species richness has increased by about 35\% through invasions (primarily of annuals from the family Poaceae). In addition, human population density, percentage of agriculture, and percentage of public lands all show a positive association with nonnative plant richness. Successful plant invasions may change the composition of species communities, basic ecological functions, and the delivery of ecosystem services. Thus, identifying the factors that influence such variation in distribution patterns can be fundamental to recognizing the present and potential future extent of nonnative plant infestations and, in turn, developing appropriate management programs.
\end{abstract}

Key words: Invasibility, invasive species, land-use type, nonnative species richness, nonnative species traits.

Invasive species are both consequences and drivers of global change (Vitousek et al. 1996), and invasions alter native species and communities (e.g., D'Antonio and Vitousek 1992; Mack et al. 2000; Mooney and Cleland 2001; Orrock et al. 2008; Pimentel et al. 2000). Invasive species can alter the structure and function of ecosystems and, in turn, the relationship among species and ecological processes and ultimately ecosystems services (Charles and Dukes 2007; Pejchar and Mooney 2009) and ecological resilience (Allen et al 2010).

Many approaches have been taken to understand and predict the occurrence and effects of biological invasions, including observational studies (Lonsdale 1999; Stohlgren et al. 1999), experimental studies (Kennedy et al. 2002; Naeem et al. 2000), and modeling (Higgins et al. 2000; Peterson et al. 2003). In turn, multiple hypotheses have been proposed

\section{DOI: 10.1614/IPSM-D-11-00007.1}

* First and fourth through eighth authors: Nebraska Invasive Species Project Coordinator and Graduate Students, Nebraska Cooperative Fish and Wildlife Research Unit, University of Nebraska, Lincoln, NE 68583-0984; second author: Unit Leader, U.S. Geological Survey, Nebraska Cooperative Fish and Wildlife Research Unit, University of Nebraska, Lincoln, NE 68583-0984; third and ninth authors: Graduate Students, University of Nebraska, Lincoln, NE 68583. Corresponding author's E-mail: kdecker4@unl.edu to explain nonnative species invasions, and frequently, these hypotheses are based on comparing characteristics between native and nonnative species (e.g., Smith and Knapp 2001; Thompson et al. 1995), identifying particular attributes of invaded habitats, or both (Blossey and Notzold 1995; Heger and Trepl 2003). For many nonnative plants, growth rate, nutrient use, stress tolerance, herbivore resistance, and seed production and dispersal are plant traits that contribute the most to successful invasion (Daehler 2003; Lloret et al. 2005; Pyšek and Richardson 2007; Rejmánek and Richardson 1996). Growth form (annual, biennial, perennial, forb, shrub, etc.) and life form (Phanerophytes, Chamaephytes, etc.) are the most frequently examined traits; however, few patterns are consistent across studies (Pyšek and Richardson 2007).

Nonnative species distribution may be associated with land use, land cover, and human activities, such as those creating transportation corridors, agriculture, and recreation (D'Antonio and Vitousek 1992; Larson et al. 2001; Mack et al. 2000; Pimentel et al. 2000; Pyšek et al. 2010; Sutton et al. 2007). For example, urban areas often contain a relatively high number of nonnative species (McKinney 20012006 ; Rejmánek 2003); the flora in European cities can have up to twice the proportion of nonnative species compared with neighboring rural areas (Pyšek 1998; Roy et al. 1999). Many nonnative plants are introduced through landscaping, which, in turn, is correlated with human population density. In 
addition, studies have noted that grasslands tend to have fewer nonnative species (Maskell et al. 2006; Pyšek et al. 2002 2010) when compared with surrounding nongrassland areas.

Factors influencing nonnative plant richness include taxa, habitat quality, native species diversity, and other variables (Mack et al. 2000). Given the effects that nonnative species can have on native biodiversity (Heywood 1989), disturbance regimes (D'Antonio and Vitousek 1992), and ecosystem structure and function (Chapin et al. 2000; Vitousek et al. 1997), it is important to identify what factors may be contributing to nonnative species distributions. Several recent studies have described nonnative plant attributes or examined associations of nonnative plant distribution and land use (Lloret et al. 2005; McKinney 2006; Pysek et al. 2010; Radford and Cousens 2000), and some have attempted to do both in a single study (Vicente et al. 2010; Whitney and Gabler 2008). But, studies tend to examine only a few species (Ibanez et al. 2009; Van Clef and Stiles 2001), which limits inference across species, or the studies that do examine larger suites of species may only examine associations with one particular land-use type (e.g., GavierPizarro et al. 2010; Lundgren et al. 2004). In addition, few studies have investigated diverse groups of nonnative species at a broad scale (but see Gavier-Pizarro et al. 2010; Ibanez et al. 2009; Pysek et al 2010). Research at broad spatial scales has important theoretical and management implications because biological invasions are detrimental to many ecosystem functions and processes and can affect ecological resilience (Allen and Holling 2010).

Using data from the Nebraska flora, our goals were to (1) characterize native and nonnative plant species by their growth and life form, (2) examine the distribution of native and nonnative species by habitat type, (3) determine whether human population size and land-cover attributes predict nonnative plant species richness, and (4) determine nonnative plant species richness by county. Understanding landscape associations with nonnative plant richness can potentially help us to infer introduction pathways, which may be particularly important in states, like Nebraska, where much of the landscape is privately owned (which can create additional challenges for the management of nonnative species across large landscapes). In Nebraska, more than half of the state's human population resides in three counties of eastern Nebraska, creating a population and land-use dichotomy across the landscape (urban in the east and rural in the central and west). This study offers a unique insight into nonnative plant distribution in urban vs. rural communities and the modes of nonnative plant introduction.

\section{Materials and Methods}

The geographic extent of our study was the state of Nebraska. A list of the native and nonnative plant species in Nebraska was compiled from The Flora of Nebraska (Kaul et al. 2006). Species represented by at least one herbarium specimen during the past $200 \mathrm{yr}$ and that grow outside of cultivation are represented in these data. Although sampling bias tends to occur in herbarium data, this data set was based primarily on the field data collected by the three authors of The Flora of Nebraska (Kaul et al. 2006) who collected plants in every county in Nebraska and thus is relieved of spatial bias, to some extent. Some data were obtained from herbaria records and published literature. These data, therefore, represent "snapshots" of the distributions of plant species. Species occurrences were assessed by collections within a county. Information on life and growth form and resident habitat was also obtained from The Flora of Nebraska (Kaul et al. 2006). Habitat categories were based on the wetland indicator codes from the U.S. Department of Agriculture (USDA) Natural Resource Conservation Service PLANTS database (2010).

We obtained county-level demographic data (human population size as of July 2009 and county area) from the Nebraska Department of Natural Resources website (2010). We acquired land cover (percentage of grassland and percentage of agricultural development) from the Great Plains Geographic Information System Partnership (Bishop et al. 2009) and obtained public lands data from the U.S. Geological Survey, National Biological Information Infrastructure, Gap Analysis Program (2010). We used ArcGIS ${ }^{1}$ 9.0 to calculate the percentage of grassland, the percentage of agriculture, and the percentage of public lands per county using the Nebraska County map shapefile ${ }^{2}$ from the Nebraska Department of Natural Resources (2010).

We calculated nonnative species richness and normalized the data by the geographic area of each county. We also normalized human population data by the geographic area of each county to obtain density estimates. Several variables (nonnative species richness, human population, and percentage of public lands) were natural-log-transformed to meet the statistical assumption of normalcy.

We used an information-theoretical model selection approach to weigh evidence among multiple competing hypotheses, which can be beneficial when there are several predictors with multiple combinations expected (Burnham and Anderson 2002). We created regression models to predict county-level richness of nonnative plant species and used Akaike Information Criterion (AIC) and informationtheoretical model selection (Burnham and Anderson 2002) to compare 12 different models (Table 1) and determine which variables (percentage of agriculture, percentage of grasslands, percentage of public lands, and human population density) influence nonnative plant richness. The effect of each variable on nonnative plant richness was measured independently (single-variable models) and in a few combinations. Because human movements may contribute to the observed distribution of nonnative plants, we also included a model with percentage of public lands and human 
Table 1. Results from the information-theoretical model selection, comparing all 12 separate candidate models to identify factors that influence nonnative plant distribution in Nebraska. Results suggest that all four variables (human population density, percentage of grasslands, percentage of agriculture, and percentage of public lands) influence nonnative plant richness., ${ }^{\text {a, }}$

\begin{tabular}{|c|c|c|c|c|c|c|}
\hline Model & Ln likelihood & $K$ & $n$ & $\mathrm{AIC}_{c}$ & $\Delta \mathrm{AIC}_{c}$ & $w_{i}$ \\
\hline Agriculture + population + public lands & -40.99 & 5 & 93 & 92.69 & 0 & 0.61 \\
\hline Agriculture + grasslands + population + public lands & -40.44 & 6 & 93 & 93.86 & 1.18 & 0.34 \\
\hline Grasslands + population + public lands & -43.83 & 5 & 93 & 98.34 & 5.66 & 0.04 \\
\hline Population + public lands & -46.26 & 4 & 93 & 100.97 & 8.28 & 0.01 \\
\hline Agriculture + grasslands + population & -55.01 & 5 & 93 & 120.71 & 28.02 & 0.00 \\
\hline Agriculture + population & -56.89 & 4 & 93 & 122.23 & 29.55 & 0.00 \\
\hline Population & -58.15 & 3 & 93 & 122.57 & 29.88 & 0.00 \\
\hline Agriculture + grasslands + public lands & -65.45 & 5 & 93 & 141.59 & 48.90 & 0.00 \\
\hline Public lands & -74.82 & 3 & 93 & 155.92 & 63.23 & 0.00 \\
\hline Agriculture + public lands & -74.22 & 4 & 93 & 156.89 & 64.21 & 0.00 \\
\hline Grasslands & -75.81 & 3 & 93 & 157.89 & 65.21 & 0.00 \\
\hline Agriculture & -90.08 & 3 & 93 & 186.49 & 93.74 & 0.00 \\
\hline
\end{tabular}

a Abbreviations: In likelihood, natural logarithm of the likelihood function; $K$, the number of parameters in the model, including the intercept; $n$, sample size; $\mathrm{AIC}_{c}$, Akaike information criterion corrected for small sample sizes; $\Delta \mathrm{AIC}_{c}$, difference in $\mathrm{Akaike}_{\text {information }}$ criterion corrected for small sample sizes relative to the best-fitting model; and $w_{\mathrm{i}}=$ Akaike weight, scaled 0 to 1 , which indicates the degree of relative support for a model.

${ }^{\mathrm{b}}$ We identified the most parsimonious models (i.e., those that provide the best fit of the data) as those within $10 \%$ of the weight of the highest-ranking model.

population density. The final model included all four variables together. We calculated differences in AIC values between the best model (lowest AIC) and the other models to rank them in relation to their support based on the data. We identified the most parsimonious models (i.e., those that provided the best fit of the data) as those within $10 \%$ of the weight of the highest-ranked model.

\section{Results}

There were 1,545 native and 459 nonnative plant species documented in Nebraska. Native plants were primarily perennials $(72 \%)$, but nonnative plants were primarily annuals (51\%; Figure 1a). Forbs (herbaceous flowering plants, excluding grasses) were the most common growth form for both native and nonnative plants. However, more of the native plants were perennial forbs $(47 \%)$, and more of the nonnative plants were annual forbs (35\%; Figure 1b). Native and nonnative species consisted of 136 and 79 different families, respectively, and most families represented less than $10 \%$ of the total, with the exception of Asteraceae (15\% native, $11 \%$ nonnative) and Poaceae (10\% native, $17 \%$ nonnative). Both native and nonnative plants were most frequently found in upland-type habitat $(39.5 \%$ and $51.6 \%$, respectively; Figure 2 ). However, a higher proportion of native plants occurred in wetland habitats than the proportion of nonnative plants (Figure 2).

We created regression models to predict county-level richness of nonnative plant species and used Akaike
Information Criterion (AIC) and information-theoretical model selection (Burnham and Anderson 2002) to compare the 12 different plausible models (Table 1) and to determine which variables (percentage of agriculture, percentage of grasslands, percentage of public lands, and human population density) influence nonnative plant richness. Information-theoretical model selection identified two models that were best supported by the data, that is, those that were within $10 \%$ of the weight of the highest-ranked model (Table 1). The top-ranked models suggested that all three land-cover attributes influence nonnative plant species richness in Nebraska, however, with varying strengths and in opposing directions. Nonnative plant richness increases with increasing agriculture (albeit weakly) and with public lands and decreases with increasing grasslands (Figures $3 \mathrm{a}-\mathrm{c}$ ) at the county level. Human population density is also included in the top-ranked models and has a positive association with nonnative plant richness (Figure 3d). The lowest-ranked models, those not supported by our data, included only single variables (i.e., percentage of agriculture, percentage of grasslands, etc.), suggesting that these factors alone do not influence nonnative plant richness but rather a combination of factors as shown by the top-ranked models.

The spatial distribution of nonnative plant species richness indicates that counties in the northeastern corner of the state (Figure 4) have more nonnative species. This region of Nebraska has relatively high human population densities and a large percentage of agriculture. In contrast, nonnative species occur less frequently in the north-central 


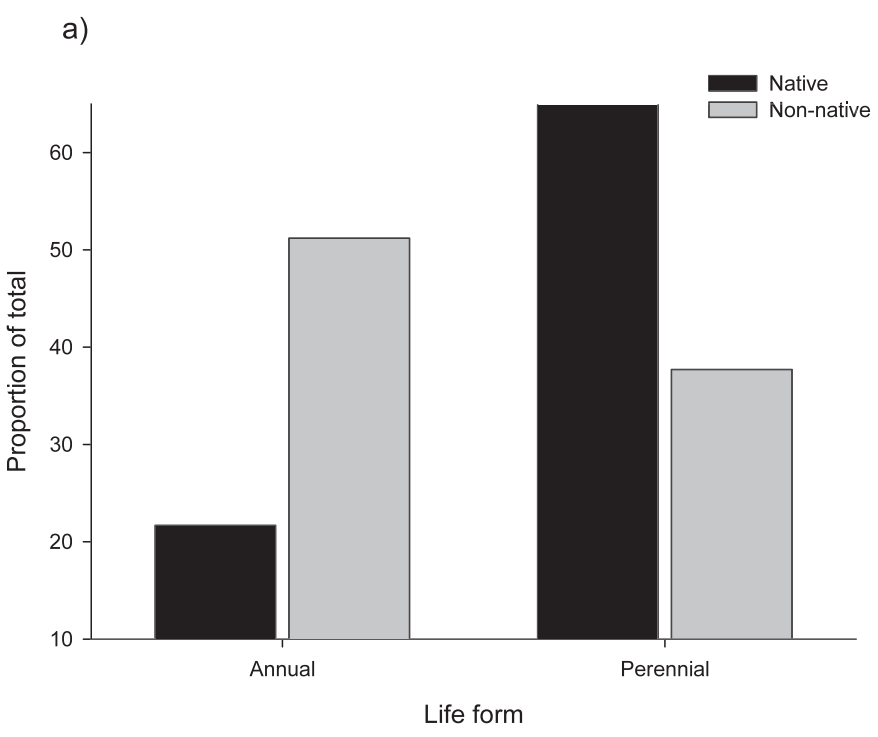

b)

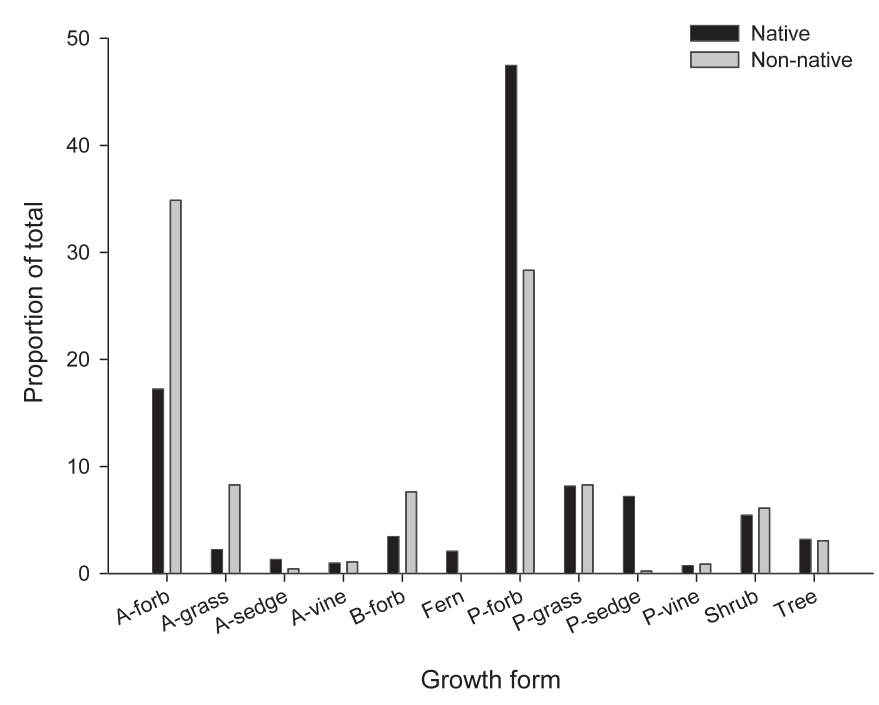

Figure 1. The proportion of native and nonnative plants in Nebraska that are (a) annual vs. perennial, and (b) that represent different growth forms. There is a strong tendency for nonnative species to be annuals rather than perennials. Abbreviations: A, annual; B, biennial; P, perennial.

portion of the state, where much of the land is dominated by grasslands, and human population density is low.

\section{Discussion}

Invasion success is affected by intrinsic attributes of species and characteristics of the invaded habitat (Stohlgren et al. 1999). In Nebraska, nonnative plants were more likely to be annuals than perennials (mostly forbs and grasses; Figure 2), which could lead to scenarios that select against

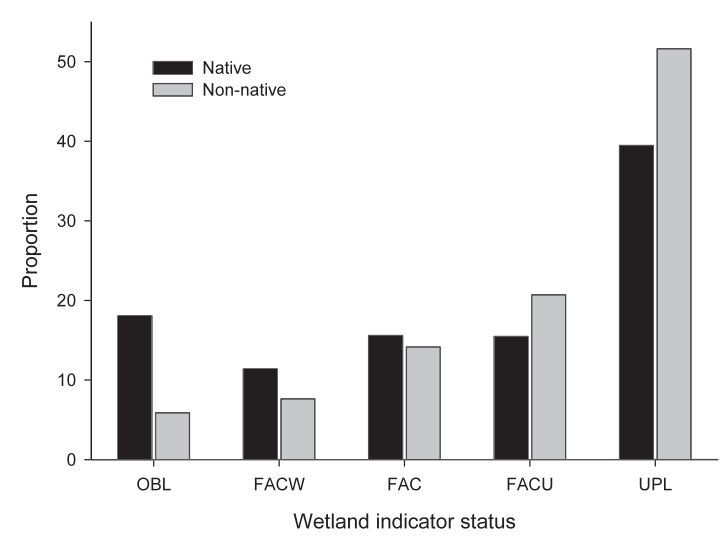

\begin{tabular}{ccl}
\hline Code* & Wetland Type & \multicolumn{1}{c}{ Description } \\
\hline OBL & Obligate Wetland & $\begin{array}{l}\text { Occurs almost always (estimated probability 99\%) under natural } \\
\text { conditions in wetlands. }\end{array}$ \\
FACW & $\begin{array}{c}\text { Facultative } \\
\text { Wetland } \\
\text { Usually occurs in wetlands (estimated probability 67\%-99\%), but } \\
\text { occasionally found in non-wetlands. }\end{array}$ \\
FAC & Facultative & $\begin{array}{l}\text { Equally likely to occur in wetlands or non-wetlands (estimated } \\
\text { probability 34\%-66\%) } \\
\text { Fsually occurs in non-wetlands (estimated probability 67\%-99\%), } \\
\text { but occasionally found on wetlands (estimated probability 1\%- } \\
33 \%) .\end{array}$ \\
FPL & Obligate Upland & $\begin{array}{l}\text { Occurs in wetlands in another region, but occurs almost always } \\
\text { (estimated probability 99\%) under natural conditions in non- } \\
\text { wetlands. }\end{array}$ \\
\hline *Adapted from the USDA, NRCS PLANTS Database
\end{tabular}

Figure 2. The proportion of native and nonnative plants in Nebraska found in each of five different habitat categories (adapted from the wetland indicator codes as described by the U.S. Department of Agriculture, Natural Resources Conservation Service PLANTS database). The $\mathrm{x}$-axis represents a gradient ranging from wetland-dependant species to entirely upland species.

native species. For example, nonindigenous grasses have been shown to increase the amount and continuity of fuel load and fire frequency, which inhibits less fire tolerant native species (Briske et al. 2006). In addition, our data showed that the proportion of trees and shrubs was similar between native and nonnative species (less than 20\% combined; Figure 2), and a greater proportion of nonnative plants were present in uplands (Figure 3), which is not surprising because upland habitat constitutes $>80 \%$ of the landscape. However, these species warrant further study because trees and shrubs may actually have greater per capita effects than do forbs in Midwest ecosystems, especially in upland habitats.

Information-theoretical model selection suggested that all four variables (human population density, percentage of grasslands, percentage of agriculture, and percentage of public lands) influence nonnative plant richness (Table 1). Models that included only a single variable (i.e., percentage of agriculture, percentage of grasslands, etc.) ranked lowest among the 12 candidate models, suggesting that those factors, alone, do not influence nonnative plant richness. 

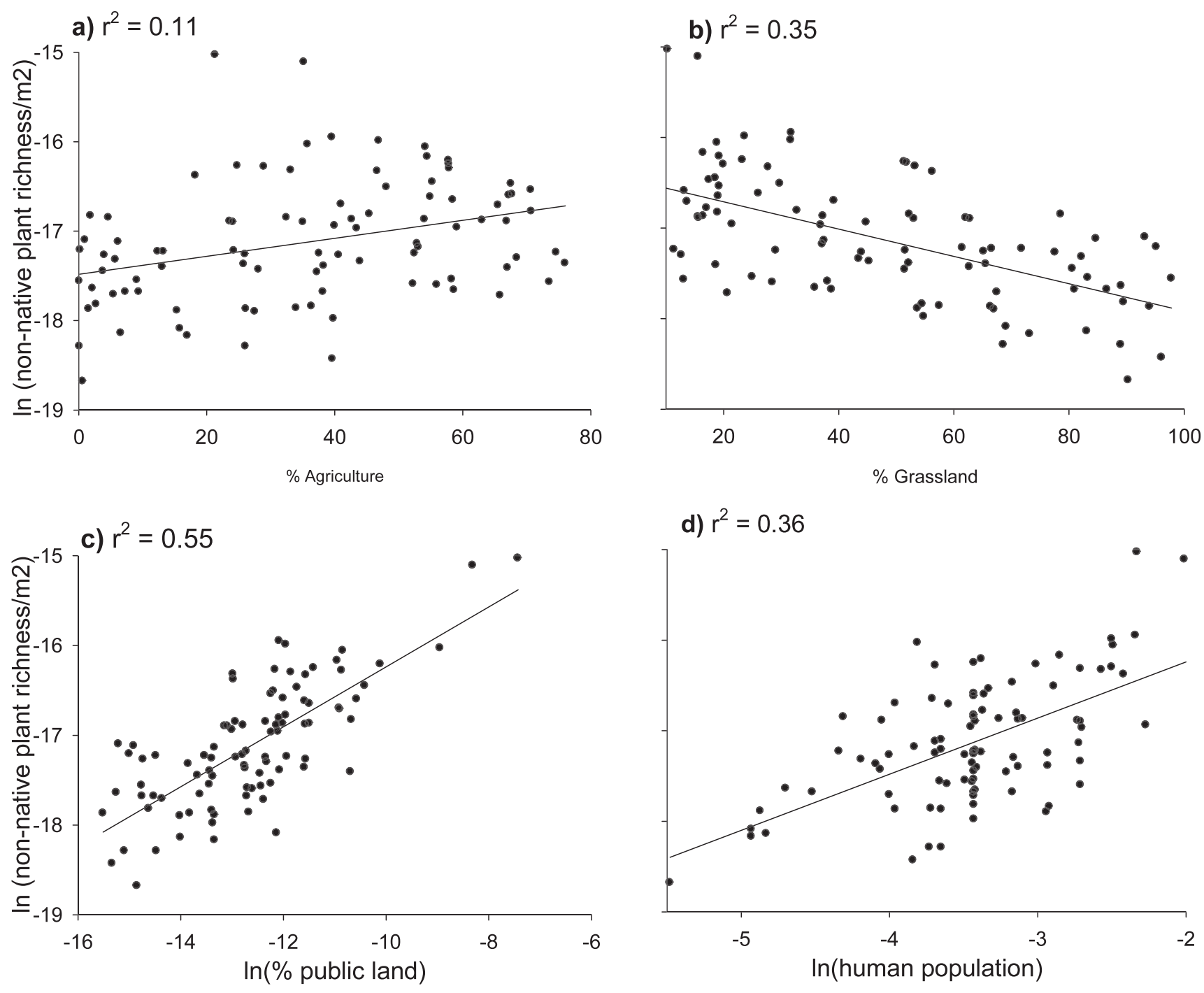

Figure 3. The relationship between nonnative plant richness in Nebraska counties and three land-cover attributes: (a) percentage of agriculture, (b) percentage of grasslands, (c) percentage of public lands, and (d) human population density. The information-theoretical model selection approach suggests each variable influences nonnative plant richness; figures display respective patterns with $r^{2}$ values. Several variables (nonnative species richness, human population, and percentage of public lands) were not normally distributed and were natural $\log$-transformed to meet the assumptions of normality.

Similar to McKinney (2001), our results report that human population density is an important predictor of the distribution of nonnative plant species (Figure 3d). Nonnative plant species are often spread through human actions (Hodkinson and Thompson 1997), which result in close relationships between distribution patterns and human populations. For example, roads (which are more abundant in densely populated areas), can provide corridors for plant dispersal (Hodkinson and Thompson 1997; Lundgren et al. 2004). Another example is found in urban landscaping. As human population density increases, we would expect an increase in landscaping activities, and thus, the increased chance of nonnative plant dispersal through contaminated nursery stock or garden escapes (see Hodkinson and Thompson 1997).
Alternatively, certain land-cover attributes have been shown to influence nonnative species distribution. For example, in a comprehensive review of nonnative species in European habitats, Pysek et al. (2010) found that agricultural (and urban) habitats harbored the highest number of nonnative plant and insect species, whereas grasslands and scrub were generally less invaded. In Nebraska, nonnative plant richness exhibited a weak, positive association with agricultural land (Figure 3a) but decreased with an increasing percentage of grassland habitat (Figure 3b). Historical land use could potentially play a role in our findings, however, because some habitats have had longer "exposure" to nonnative species than others (habitats with longer exposure to nonnatives can potentially be more vulnerable to invasions). 


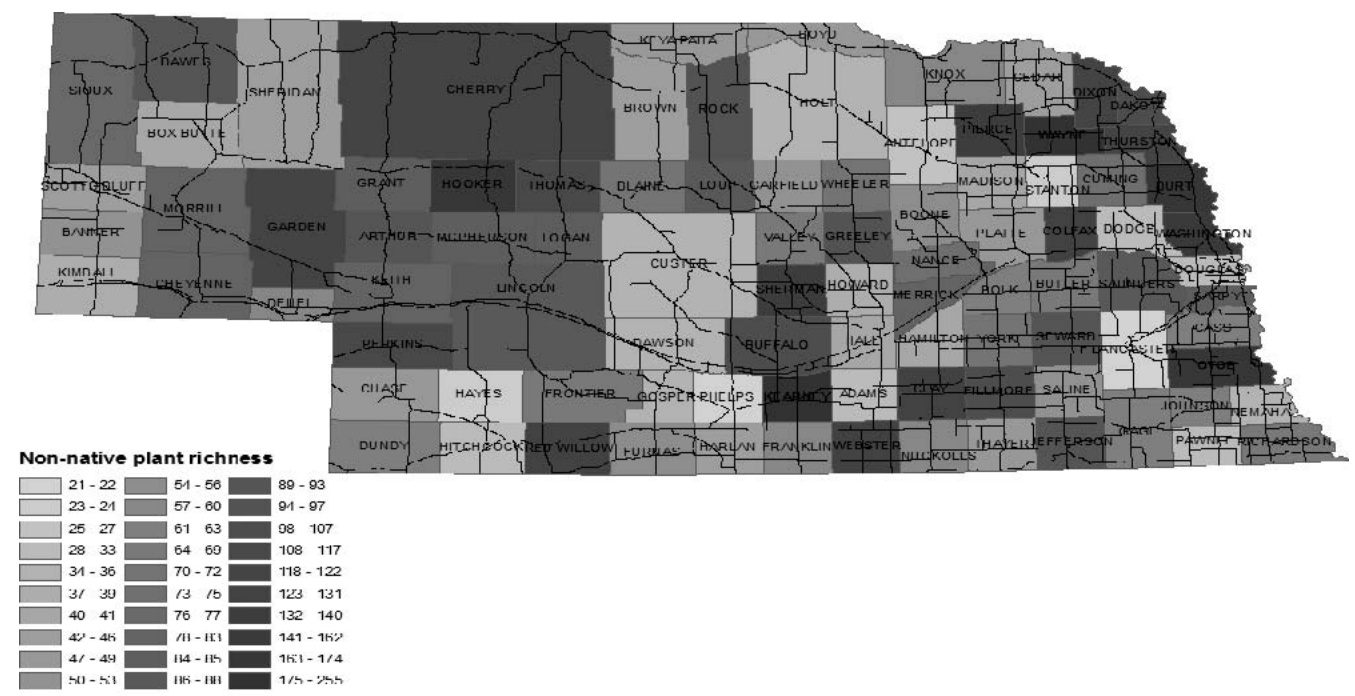

Figure 4. The spatial distribution of nonnative plant species richness across Nebraska counties.

Information pertaining to historic land use is limited in Nebraska, and further research in this area remains. Nonnative plant seeds have historically been dispersed as impurities in grain (Salisbury 1961), but improved seedcleaning techniques and the use of herbicides appear to have decreased the number of nonnative seeds in commercial seed (Tonkin 1982). Agricultural machinery and the associated disturbance created may explain the increase in nonnative plant richness with a higher proportion of agriculture in a county. Although agriculture seed is far less contaminated than it was, machinery can carry viable seeds (Bakker 1989), perhaps picked up from ditches or roadsides, and disperse them between sites scattered across relatively long distances (McCanny and Cavers 1988).

In Nebraska, grasslands have higher native-plant diversity than do agriculture lands (K. L. Decker, unpublished data). Given that nonnative plant richness declines with increasing percentage of grasslands in a county, we examined whether those patterns lend support for the Diversity Resistance hypothesis (communities of high diversity will be more resistant to invasion; Elton 1958; Kennedy et al. 2002). Scale, however, seems to play an important role in determining that relationship because the hypothesis appears to be supported at small scales (Kennedy et al. 2002; Naeem et al. 2000; Stohlgren et al. 1999) but not necessarily at broader scales (Allen et al. 2009; Stohlgren et al. 1999). Habitat type may also influence the relationship between native and nonnative species richness. For example, wet meadows and aspen habitats show high numbers of both native and nonnative species (Stohlgren et al. 1999). In contrast, our results suggest that both native and nonnative species tend to occur more frequently in upland habitats compared with wetlands (Figure 2), although there were proportionally more native plants in the wetlands than there were nonnative plants.
Although additional factors (disturbance, climate, etc.) may have confounded our results, this study suggests that, at a large scale, more-diverse habitats, such as grasslands, may be able to resist or constrain invasion by nonnative plants better than do less-diverse habitats (agriculture). However, recent reviews suggest that high-diversity communities constrain the abundance of invasive species once introduced, rather than resisting invasion (Levine et al. 2004), and thus, studies examining nonnative introductions and dispersal into diverse and lessdiverse habitats in Nebraska are required to further advance our understanding of this pattern.

Previous studies have shown a relationship between the number of nonnative species in nature reserves and the number of human visitors (Lonsdale 1999). This pattern might help explain the positive relationship between nonnative plant richness and the percentage of public lands found in this study; counties with a higher percentage of public lands tend to have higher, relative, nonnative plant richness. However, we expected public areas to be more rigorously managed for nonnative species, which contradicts our findings. In Nebraska, public lands comprise only about $2.5 \%$ of the total land area; however, human activity in these areas may be greater than it is on private lands. Increased human traffic in public areas, including parks and other outdoor recreation facilities, creates high disturbance levels and increases the potential for nonnative species introductions (Pimentel et al. 2005). Alternatively, the positive relationship between nonnative plant richness and the percentage of public lands may reflect the fact that specimens are more likely to be found and documented from public lands and thus may represent an increased effort in identifying nonnative plants in public areas. Historical use of public vs. private lands may also play a role in nonnative species distribution. However, information regarding historic land use is limited, and further 
research in this area is needed. The spatial distribution of nonnative plant-species richness in Nebraska (Figure 4) provides some insights. More than $50 \%$ of the state's total human population resides in the eastern portion of the state, and not surprisingly, that area has high nonnative plant richness. In addition, the largest tracts of public land (refuges, national forests) are found in the north-central and northwestern areas of the state (which have relatively high nonnative plant richness; see Figure 4). This pattern corresponds to our finding of a positive association between the percentage of public lands and nonnative plant richness. Although natural discontinuities can occur across the landscape, neighboring counties with dissimilar richness values may reflect uneven sampling, to some extent. Nebraska contains four separate ecoregions, with tall-grass prairie in the east and short-grass prairie in the west (Schneider et al. 2005). Further exploration of these data and historical land-use data may lead to associations between these ecoregions (and landchanges within each region) and nonnative plant distribution.

Many attempts have been made to characterize the attributes of nonnative species to determine their ability to successfully establish in habitats (Crawley et al. 1995; Thompson et al. 1995; Williamson and Fitter 1996). Despite generalizations linking invasive species with "disturbed" habitats, for example, no trait or suite of traits has been consistently associated with successful invasion (e.g., Forys and Allen 1999). However, studies that compare characteristics of native species to nonnative species may broaden our understanding and help develop better management strategies (e.g., Rejmanek and Richardson 1996; Smith and Knapp 2001; Thompson et al. 1995). We found that, in Nebraska, nonnative plant species tended to be annuals (which are typically fast growing, short lived, and produce large numbers of seeds) and likely exhibit characteristics that facilitate their introduction and subsequent spread in susceptible habitats (Bazzaz 1986). There is little indication that the rate of introductions has decreased or reached an asymptote, and if landscape change continues, annuals may well dominate many floras. The change from a perennial flora to an annual flora can increase nitrate leaching, alter fire regimes, and decrease carbon storage (Christian and Wilson 1999; D’Antonio and P.M. Vitousek 1992; Dyer and Rice 1999). In addition, invaded ecosystems (such as these) present a unique framework for examining ecosystem resilience, that is, the ability of systems of people and nature to absorb disturbance without collapsing and reorganizing around a new process regime (Gunderson et al. 2009; Holling 1973). Invasions change the functions present in a system, and the relationship among species and ecological processes and structures. Invasions can reduce resilience and, in combination with other factors, such as natural or amplified disturbances, lower or raise the thresholds to regime changes. In Nebraska, the potential shift from perennial to annual flora may not only influence ecosystem services but likely lead to a regime change, indicating that resilience has been exceeded. Further research that quantifies changes in ecological structure, process, function, and services and in native species recovery are required to explore how invasive, nonnative species can affect the resilience of ecological systems. Ultimately, understanding the thresholds of particular landuse types (public lands, agricultural lands, etc.) along with the attributes of invasive species will help to predict and ameliorate against their impacts.

\section{Sources of Materials}

\author{
${ }^{1}$ ArcGIS software, version 9.0, ESRI, 380 New York Street, \\ Redlands, CA 92373-8100. \\ ${ }^{2}$ MAF/TIGER (Master Address File/Topologically Integrated \\ Geographic Encoding and Referencing) database, U.S. Census Bureau, \\ 4600 Silver Hill Road, Washington, DC 20233.
}

\section{Acknowledgments}

The Nebraska Cooperative Fish and Wildlife Research Unit is jointly supported by a cooperative agreement between the U.S. Geological Survey; the Nebraska Game and Parks Commission; the University of Nebraska, Lincoln; the U.S. Fish and Wildlife Service; and the Wildlife Management Institute. Any use of trade names is for descriptive purposes only and does not imply endorsement by the U.S. Government. We thank the U.S. Geological Survey National Biological Information Infrastructure, Gap Analysis Program, and the Rainwater Basin Joint Venture for the use of land-cover data.

\section{Literature Cited}

Allen, C. R. and C. Holling. 2010. Novelty, adaptive capacity, and resilience. Ecol. Soc. 15:24. http://www.ecologyandsociety.org/vol15/ iss3/art24/. Accessed: April 15, 2011.

Allen, J. A., C. S. Brown, and T. J. Stohlgren. 2009. Non-native plant invasions of United States National Parks. Biol. Invasions 11: 2195-2207.

Bakker, J. P. 1989. Nature management by grazing and cutting. London: Kluwer Academic.

Bazzaz, F. A. 1986. Life history of colonizing plants: some demographic, genetic, and physiological features. Pages 96-110 in H. G. Baker, H. A. Mooney, and J. A. Drake, eds. Ecology of Biological Invasions of North America and Hawaii. New York: Springer-Verlag.

Bishop, A., J. Liske-Clark, and R. Grosse. 2009. Nebraska Land Cover Development. Grand Island, NE: Great Plains Geographic Information Service Partnership, U.S. Fish and Wildlife Service.

Blossey, B. and R. Notzold. 1995. Evolution of increased competitive ability in invasive nonindigenous plants: a hypothesis. J. Ecol. 83:887-889.

Briske, D. D., S. D. Fuhlendorf, and F. E. Smeins. 2006. A unified framework for assessment and application of ecological thresholds. Range Ecol. Manag. 59:225-236.

Burnham, K. P. and D. R. Anderson. 2002. Model selection and multimodel inference: a practical information-theoretical approach. 2nd ed. New York: Springer.

Chapin F. S., E. S. Zavaleta, V. T. Eviner, R. L. Naylor, P. M. Vitousek, H. L. Reynolds, D. U. Hooper, S. Lavorel, O. E. Sala, S. E. Hobbie, M. C. Mack, and S. Diaz. 2000. Consequences of changing biodiversity. Nature 405:234-242. 
Charles, H. and J. S. Dukes. 2007. Impacts of invasive species on ecosystem services. Pages 217-237 in W. Nentwig, ed. Biological Invasions (Ecological Studies, Vol. 193). Berlin: Springer-Verlag.

Christian, J. M. and S. D. Wilson. 1999. Long-term ecosystem impacts of an introduced grass in the northern Great Plains. Ecology 80: 2397-2407.

Crawley, M. J. and S. L. Brown. 1995. Seed limitation and the dynamics of feral oilseed rape on the M25 motorway. Proc. R. Soc. Lond. B Biol. Sci. 259:49-54.

Daehler, C. C. 2003. Performance comparisons of co-occurring native and alien plants: Implications for conservation and restoration. Annu. Rev. Ecol. Syst. 34:183-211.

D'Antonio, C. M. and P. M. Vitousek. 1992. Biological invasions by exotic grasses, the grass/fire cycle, and global change. Annu. Rev. Ecol. Syst. 23:63-87.

Dyer, A. R. and K. J. Rice. 1999. Effects of competition on resource availability and growth of a California bunchgrass. Ecology 80: 2697-2710.

Elton C. S. 1958. The Ecology of Invasions by Animals and Plants. London: Methuen.

Forys, E. A. and C. R. Allen. 1999. Biological invasions and deletions: community change in south Florida. Biol. Conserv. 87:341-347.

Gavier-Pizarro, G., V. Radeloff, S. Stewart, C. Huebner, and N. Keuler. 2010. Housing is positively associated with invasive exotic plant species richness in New England, USA. Ecol. Appl. 20:1913-1925.

Gunderson, L., C. R. Allen, and C. S. Holling. 2009. Foundations of Resilience. New York: Island.

Heger, T. and L. Trepl. 2003. Predicting biological invasions. Biol. Invasions 5:313-321.

Heywood, V. 1989. Patterns, extents and modes of invasions by terrestrial plants. Pages 31-60 in J. A. Drake, H. A. Mooney, F. di Castri, R. H. Groves, F. J. Kruger, M. Rejmánek, and M. Williamson, eds. Biological Invasions: A Global Perspective. New York: J. Wiley.

Higgins, S. I., D. M. Richardson, and R. M. Cowling. 2000. Using a dynamic landscape model for planning the management of alien plant invasions. Ecol. Appl. 10:1833-1848.

Hodkinson, D. J. and K. Thompson. 1997. Plant dispersal: the role of man. J. Appl. Ecol. 34:1484-1496.

Holling, C. S. 1973. Resilience and stability of ecological systems. Annu. Rev. Ecol. Syst. 4:1-23.

Ibanez, I., J. A. Silander, A. M. Wilson, N. LaFleur, N. Tanaka, and I. Tsuyama. 2009. Multivariate forecasts of potential distributions of invasive plant species. Ecol. Appl. 19:359-375.

Kaul, R. B., D. Sutherland, and S. Rolfsmeier. 2006. The Flora of Nebraska. Lincoln, NE: School of Natural Resources, University of Nebraska.

Kennedy, T. A., S. Naeem, K. M. Howe, J.M.H. Knops, D. Tilman, and P. Reich. 2002. Biodiversity as a barrier to ecological invasion. Nature 417:636-638.

Larson, D. L., P. J. Anderson, and W. Newton. 2001. Alien plant invasion in mixed-grass prairie: effects of vegetation type and anthropogenic disturbance. Ecol. Appl. 11:128-141.

Levine, J. M., P. B. Adler, and S. G. Yelenik. 2004. A meta-analysis of biotic resistance to exotic plant invasions. Ecol. Lett. 7:975-989.

Lloret, F., F. Medail, G. Brundu, I. Camarda, E. Moragues, J. Rita, P. Lambdon, and P. E. Hulme. 2005. Species attributes and invasion success by alien plants on Mediterranean islands. J. Ecol. 93:512-520.

Lonsdale, W. M. 1999. Global patterns of plant invasions and the concept of invasibility. Ecology 80:1522-1536.

Lundgren, M. R., C. J. Small, and G. D. Dreyer. 2004. Influence of land use and site characteristics on invasive plant abundance in the Quinebaugh Highlands of southern New England. Northeast. Nat. 11:313-332.
Mack, R. N., D. Simberloff, W. M. Lonsdale, H. Evans, M. Clout, and F. Bazzaz. 2000. Biotic invasions: causes, epidemiology, global consequences, and control. Ecol. Appl. 10:689-710.

Maskell, L. C., J. M. Bullock, S. M. Smart, K. Thompson, and P. E. Hulme. 2006. The distribution and habitat associations of non-native plant species in urban riparian habitats. J. Veg. Sci. 17:499-508.

McCanny, S. J. and P. B. Cavers. 1988. Spread of proso millet (Panicum miliaceum L.) in Ontario, Canada, II: dispersal by combines. Weed Res. 28:67-72.

McKinney, M. L. 2001. Effects of human population, area and time on nonnative plant and fish diversity in the United States. Biol. Conserv. 100:243-252.

McKinney, M. L. 2006. Urbanization as a major cause of biotic homogenization. Biol. Conserv. 127:247-260.

Mooney, H. A. and E. E. Cleland. 2001. The evolutionary impact of invasive species. Proc. Natl. Acad. Sci. U. S. A. 98:5446-5451.

Naeem, S., J.M.H. Knops, D. Tilman, K. M. Howe, T. Kennedy, and S. Gale. 2000. Plant diversity increases resistance to invasion in the absence of covarying extrinsic factors. Oikos 91:97-108.

Nebraska Department of Natural Resources. Data Bank: Political Boundary Databases, http://www.dnr.ne.gov/databank/statewide.html Accessed April 8, 2010.

Orrock, J. L., M. S. Witter, and O. J. Reichman. 2008. Apparent competition with an exotic plant reduces native plant establishment. Ecology 89:1168-1174.

Pejchar, L. and H. A. Mooney. 2009. Invasive species, ecosystem services and human well-being. Trends Ecol. Evol. 24:497-504.

Peterson, A. T., M. Papes, and D. A. Kluza. 2003. Predicting the potential invasive distributions of four alien plant species in North America. Weed Sci. 51:863-868.

Pimentel, D., L. Lach, R. Zuniga, and D. Morrison. 2000. Environmental and economic costs of nonindigenous species in the United States. Bioscience 50:53-65.

Pimentel, D., R. Zuniga, and D. Morrison. 2005. Update on the environmental and economic costs associated with alien-invasive species in the United States. Ecol. Econ. 52:273-288.

Pyšek, P., V. Jarošík, and T. Kucera. 2002. Patterns of invasion in temperate nature reserves. Biol. Conserv. 104:13-24.

Pyšek, P. 1998. Is there a taxonomic pattern to plant invasions? Oikos 82:282-294.

Pyšek, P. and D. M. Richardson. 2007. Traits associated with invasiveness in alien plants: where do we stand? Pages 97-125 in W. Nentwig, ed. Biological Invasions (Ecological Studies, Vol. 193). Berlin: Springer-Verlag.

Pyšek, P., S. Bacher, and M. Chytrý, et al. (2010). Contrasting patterns in the invasions of European terrestrial and freshwater habitats by alien plants, insects and vertebrates. Global Ecol. Biogeogr. 19: 317-331.

Radford, I. J. and R. D. Cousens. 2000. Invasiveness and comparative life-history traits of exotic and indigenous Senecio species in Australia. Oecologia 125:531-542.

Rejmanek, M. and D. M. Richardson. 1996. What attributes make some plant species more invasive? Ecology 77:1655-1661.

Rejmánek, M. 2003. The rich get richer-responses. Front. Ecol. Environ. 1(3):122-123.

Roy, D. B., M. O. Hill, and P. Rothery. 1999. Effects of urban land cover on the local species pool in Britain. Ecography 22:507-515.

Salisbury, E. J. 1961. Weeds and Aliens. London: Collins.

Schneider, R., M. Humpert, K. Stoner, and G. Steinauer. 2005. The Nebraska Natural Legacy Project: A Comprehensive Wildlife Conservation Strategy. Lincoln, NE: Nebraska Game and Parks Commission Management Plan.

Smith, M. D. and A. K. Knapp. 2001. Physiological and morphological traits of exotic, invasive exotic, and native plant species in tallgrass prairie. Int. J. Plant Sci. 162:785-792. 
Stohlgren, T. J., D. Binkley, G. W. Chong, M. A. Kalkhan, L. D. Schell, K. A. Bull, Y. Otsuki, G. Newman, M. Bashkin, and Y. Son. 1999. Exotic plant species invade hot spots of native plant diversity. Ecol. Monogr. 69:25-46.

Sutton, J. R., T. J. Stohlgren, and K. G. Beck. 2007. Predicting yellow toadflax infestations in the Flat Tops Wilderness of Colorado. Biol. Invasions 9:783-793.

Tonkin, J.H.B. 1982. The presence of seed impurities in samples of cereal seed tested at the Official Seed Testing Station, Cambridge in the period of 1979-1981. Asp. Appl. Biol. 1:163-171.

Thompson, K., G. Hodgson, and T.C.G. Rich. 1995. Native and invasive plants: more of the same? Ecography 18:390-402.

U.S. Department of Agriculture, National Resources Conservation Service. 2010. The PLANTS Database. Greensboro, NC: National Plant Data Team, http://plants.usda.gov. Accessed: July 6, 2010.

U.S. Geological Survey, National Biological Information Infrastructure, Gap Analysis Program (GAP). May 2010. Protected Areas Database of the United States (PAD-US) Version 1.1. Reston, VA: USGS.
Van Clef, M. and E. W. Stiles. 2001. Seed longevity in three pairs of native and non-native congeners: assessing invasive potential. Northeast. Nat. 8:301-310.

Vicente, J., P. Alves, C. Randin, A. Guisan, and J. Honrado. 2010. What drives invisibility? A multi-model inference test and spatial modeling of alien plant species richness in northern Portugal. Ecography 33:1081-1092.

Vitousek, P. M., C. M. D’Antonio, L. L. Loope, M. Rejmanek, and R. Westbrooks. 1997. Introduced species: a significant component of human caused global change. N. Z. J. Ecol. 21:1-16.

Vitousek, P. M., C. M. D’Antonio, L. L. Loope, and R. Westbrooks. 1996. Biological invasions as global environmental change. Am. Sci. 84:468-78.

Whitney, K. D. and C. A. Gabler. 2008. Rapid evolution in introduced species, 'invasive traits' and recipient communities: challenges for predicting invasive potential. Diversity Distrib. 14:569-580.

Williamson, M. H. and A. Fitter. 1996. The characters of successful invaders. Biol. Conserv. 78:163-170.

Received January 26, 2011, and approved July 10, 2011. 